\title{
Perbandingan Leukosituria, Nitrit, Leukosit Esterase dengan Kultur Urin dalam Mendiagnosis Infeksi Saluran Kemih pada Anak
}

\author{
Jehan Sabriani, ${ }^{1}$ Adrian Umboh, ${ }^{2}$ Jeanette I. Ch. Manoppo
}

${ }^{1}$ Program Studi Pendidikan Dokter Fakultas Kedokteran Universitas Sam Ratulangi, Manado, Sulawesi Utara, Indonesia

${ }^{2}$ Bagian Ilmu Kesehatan Anak Fakultas Kedokteran Universitas Sam Ratulangi, Manado, Sulawesi Utara, Indonesia

Email: jijiihaaan@gmail.com

\begin{abstract}
Urinary tract infection (UTI) in children is the most common infection after upper airway infection. The diagnosis of UTI is based on urine culture, however, this examination takes a longer time and is quite expensive. Therefore, the diagnosis of UTI can also be confirmed by using leukocyturia, nitrite, and leukocyte esterase tests although they can not replace urine culture as the gold standard. This study was aimed to determine the accuracy of positive leukocyturia, positive nitrite, positive leukocyte esterase examination, combination of positive leukocyturia and nitrite examinations, positive leukocyturia and leukocyte esterase, and leukocyturia, nitrite, positive leukocyte esterase in diagnosing UTI. This was a literature review study. The results of the literature review showed that the range of accuracy of UTI diagnosis using positive leukocyte esterase examinations was 9-6.8\%, positive nitrite was $2.8-100 \%$, leukocyte esterase was $13.7-86 \%$, combination of positive leukocyturia and nitrite had a sensitivity value of $33 \%$, and specificity of $94 \%$, combination of positive leukocytic and leukocytic esterase had a sensitivity value of $70 \%$ and a specificity of $90 \%$, and combination of leukocyturia, nitrite, and leukocyte esterase had an accuracy range of $100 \%$. In conclusion, these examinations coul be used to confirm the diagnosis of UTI in children especially if the urine culture can not be performed on them.
\end{abstract}

Keywords: urinary tract infection (UTI), leukocyturia, nitrite, leukocyte esterase, urine culture, children

\begin{abstract}
Abstrak: Infeksi saluran kemih (ISK) merupakan infeksi yang paling sering terjadi pada anak setelah infeksi saluran napas atas. Diagnosis ISK ditegakkan berdasarkan hasil pemeriksaan kultur urin, namun pemeriksaan ini membutuhkan waktu yang lama dan biaya yang cukup mahal. Pemeriksaan leukosituria, nitrit, dan leukosit esterase juga membantu dalam mendiagnosis ISK, namun ketiga pemeriksaan ini belum dapat menggantikan kultur urin sebagai baku emas untuk mendiagnosis ISK. Penelitian ini bertujuan untuk mengetahui seberapa besar ketepatan pemeriksaan leukosituria positif, nitrit positif, leukosit esterase positif, gabungan pemeriksaan leukosituria dan nitrit positif, leukosituria dan leukosit esterase positif, dan gabungan leukosituria, nitrit, leukosit esterase positif dalam mendiagnosis ISK. Jenis penelitian ialah literature review. Hasil penelitian menunjukkan kisaran ketepatan diagnosis ISK menggunakan pemeriksaan leukosituria positif yaitu 9-6,8\%, nitrit positif sebesar 2,8$100 \%$, leukosit esterase sebesar 13,7-86\%, gabungan leukosituria dan nitrit positif memiliki nilai sensitivitas 33\%, dan spesifisitas sebesar 94\%, gabungan leukosituria dan leukosit esterase positif memiliki nilai sensitivitas $70 \%$ dan spesifisitas sebesar $90 \%$, serta gabungan pemeriksaan leukosituria, nitrit, dan leukosit esterase memiliki kisaran ketepatan sebesar $100 \%$. Simpulan penelitian ini ialah pemeriksan-pemeriksaan tersebut dapat membantu menegakkan diagnosis ISK pada anak terutama bila kultur urin tidak memungkinkan dilakukan.

Kata kunci: infeksi saluran kemih (ISK), leukosituria, nitrit, leukosit esterase, kultur urin, anak
\end{abstract}




\section{PENDAHULUAN}

Sistem perkemihan merupakan salah satu sistem penting dalam tubuh manusia, yang berfungsi untuk mengeluarkan zat-zat hasil metabolisme dari tubuh dalam bentuk urin. Sistem perkemihan terdiri dari organ pembentuk urin yaitu ginjal, dan struktur yang membawa urin dari ginjal untuk dieliminasi keluar tubuh yaitu ureter, kandung kemih, dan uretra. ${ }^{1}$

Salah satu penyakit yang paling sering menyerang sistem perkemihan yaitu infeksi saluran kemih (ISK). Infeksi saluran kemih ialah suatu keadaan adanya infeksi (terdapat pertumbuhan dan perkembangan bakteri) dalam saluran kemih, dengan jumlah bakteriuria yang bermakna. ${ }^{2,3}$ Insiden ISK pada tahun pertama kehidupan paling sering terjadi pada anak laki-laki dibandingkan anak perempuan, sedangkan pada usia prapubertas ditemukan ISK lebih banyak terjadi pada anak perempuan dibandingkan anak lakilaki. ${ }^{4}$ Penyakit ISK dibagi menjadi dua yaitu ISK bagian bawah atau sistitis, dan ISK bagian atas atau pielonefritis. Diagnosis ISK ditegakkan berdasarkan anamnesis, pemeriksaan fisik, dan pemeriksaan penunjang. ${ }^{4}$

Pemeriksaan penunjang yang biasa dilakukan untuk mendiagnosis ISK yaitu pemeriksaan urin seperti adanya leukosituria, nitrit, leukosit esterase, serta kultur urin. Leukosituria merupakan suatu keadaan terdapatnya leukosit dalam urin yang disebabkan oleh mikroorganisme dalam urin. Nitrit merupakan hasil oksidasi nitrat yang dilakukan oleh bakteri golongan Enterobacteriaceae. Leukosit esterase merupakan suatu keadaan dimana terdapatnya leukosit yang mengeluarkan enzim esterase yang disebabkan oleh adanya bakteri golongan Enterobacteriaceae. ${ }^{5,6}$ Kultur urin merupakan pemeriksaan baku emas untuk mendiagnosis ISK, interpretasi hasil dengan menghitung jumlah kuman yang ada pada media kultur. ${ }^{7}$

Pada anak, ISK merupakan infeksi yang paling sering terjadi setelah infeksi saluran napas. Hal ini mendorong penulis untuk mengetahui lebih lanjut mengenai pemeriksaan laboratorik yang mendukung diagnosis ISK pada anak.

\section{METODE PENELITIAN}

Penelitian ini berbentuk suatu literature review. Topik yang dipilih ialah perbandingan leukosituria, nitrit, leukosit esterase dan kultur urin dalam mendiagnosis ISK pada anak. Penelusuran literatur dilakukan pada beberapa database baik nasional maupun internasional seperti Google Scholar, PubMed, Garuda, dan Clinicalkey, serta jurnal-jurnal nasional dengan kombinasi kata kunci sebagai berikut yaitu, Infeksi Saluran Kemih (ISK), leukosituria, nitrit, leukosit esterase kultur urin, dan anak.

\section{HASIL PENELITIAN}

Pada penelitian ini diperoleh 10 literatur yang memenuhi kriteria penelitian sesuai dengan topik yang diteliti yang berasal dari beberapa negara di dunia

Tabel 1 memperlihatkan analisis dari kesepululh literatur menurut nama penulis, tahun publikasi, judul, jumlah sampel, dan hasil penelitian.

Tabel 2 memperlihatkan hasil tiga literatur yang menampilkan hasil leukosituria positif berdasarkan leukosituria positif, ISK positif, dan hasil kultur urin positif.

Tabel 3 memperlihatkan hasil enam literatur yang menampilkan nitrit positif berdasarkan mitrit positif, ISK positif, dan kultur urin positif.

Tabel 4 memperlihatkan hasil leukosit esterase positif berdasrkan leukosit esterase positif, ISK positif, dan kultur urin positif.

Tabel 5 memperlihatkan hasil leukosituria positif dan nitrit positif yang hanya didapatkan pada satu literatur dengan mencantumkan jumlah sampel, kultur urin positif, sensitivitas dan spesifitas.

Tabel 6 memperlihatkan hasil leukosituria positif dan leukosit esterase positf dengan mencantumkan kultur urin positif, sensitivitas, dan spesifitas.

Tabel 7 memperlihatkan hasil leukosituria positif, nitrit positif, dan leukosit esterase positif dengan mencantumkan sampel leukosituria, nitrit, dan leukosit esterase positif, dan yang disertai kultur urin positif. 
80 Medical Scope Journal (MSJ), Volume 2, Nomor 2, Januari-Juni 2021, hlm. 78-86

Tabel 1. Hasil analisis dari 10 literatur yang digunakan dalam penelitian ini

\begin{tabular}{|c|c|c|c|c|}
\hline No & Nama, tahun & Judul & $\begin{array}{l}\text { Jumlah } \\
\text { Sampel }\end{array}$ & Hasil \\
\hline 1. & $\begin{array}{l}\text { Tusino A, } \\
\text { Widyaningsih } \\
\mathrm{N}, 2018 .^{8}\end{array}$ & $\begin{array}{l}\text { Karakteristik infeksi } \\
\text { saluran kemih pada } \\
\text { anak usia } 0-12 \text { tahun } \\
\text { di RS } \\
\text { x kebumen jawa } \\
\text { tengah }\end{array}$ & 34 & $\begin{array}{l}3(9 \%) \text { anak dengan positif leukosituria positif } \\
34(100 \%) \text { positif kultur urin }\end{array}$ \\
\hline 2. & $\begin{array}{l}\text { Tullus K, } \\
\text { Shaikh N, } \\
2020 .^{9}\end{array}$ & $\begin{array}{l}\text { Urinary tract infections } \\
\text { in children }\end{array}$ & 1686 & $\begin{array}{l}586(34,7 \%) \text { positif leukosit esterase. } \\
504 \text { positif leukosit esterase dan kultur urin } \\
(86 \%) \\
226(13,4 \%) \text { positif nitrit. ( } 86 \%) \\
200 \text { positif nitrit dan kultur urin }(88 \%) \\
542(32,1 \%) \text { positif kultur urin }\end{array}$ \\
\hline 3 & $\begin{array}{l}\text { Mahajan P, } \\
2020 .{ }^{10}\end{array}$ & $\begin{array}{l}\text { Accuracy of the } \\
\text { urinalysis for urinary } \\
\text { tract infections in } \\
\text { febrile infants } 60 \text { days } \\
\text { and younger }\end{array}$ & 4147 & $\begin{array}{l}1944(46,8 \%) \text { positif nitrit } \\
111 \text { positif nitrit dan kultur urin }(2,8 \%) \\
3894(93,8 \%) \text { positif leukosit esterase } \\
267 \text { positif leukosit esterase dan kultur urin }(13 \text {, } \\
7 \%) \\
289(7,0 \%) \text { positif kultur urin }\end{array}$ \\
\hline 4. & $\begin{array}{l}\text { Schroeder AR, } \\
\text { Chang PW, } \\
\text { Shen MW, } \\
\text { Biondi EA, } \\
\text { Greenhow TL, } \\
2015 .^{11}\end{array}$ & $\begin{array}{l}\text { Diagnostic accuracy of } \\
\text { the urinalysis for } \\
\text { urinary tract infection } \\
\text { in infants }<3 \text { months of } \\
\text { age }\end{array}$ & $\begin{array}{c}325 \\
(\mathrm{LE}) \\
358(\mathrm{~N})\end{array}$ & $\begin{array}{l}212(65,2 \%) \text { positif leukosit esterase } \\
210(65 \%) \text { positif kultur urin } \\
205 \text { positif leukosit esterase dan kultur urin } \\
(96,6 \%) \\
96(39,5 \%) \text { positif nitrit } \\
243(68 \%) \text { positif Kultur urin } \\
96 \text { positif nitrit dan kultur urin }(100 \%)\end{array}$ \\
\hline 5. & $\begin{array}{l}\text { Triasta T, } \\
\text { Setiabudi D, } \\
\text { Rachmadi D, } \\
2016 . .^{12}\end{array}$ & $\begin{array}{l}\text { Faktor risiko } \\
\text { kecurigaan infeksi } \\
\text { saluran kemih pada } \\
\text { anak laki-laki usia } \\
\text { sekolah dasar }\end{array}$ & 120 & $\begin{array}{l}5(4,2 \%) \text { positif leukosituria } \\
2(1,7 \%) \text { positif leukosit esterase } \\
1(0,8 \%) \text { positif nitrit }\end{array}$ \\
\hline 6 & $\begin{array}{l}\text { Trihono P, } \\
\text { Dewi AC, } \\
\text { Gunardi H, } \\
\text { Oswari H, } \\
2012 .{ }^{13}\end{array}$ & $\begin{array}{l}\text { Prevalence of urinary } \\
\text { tract infection in 2-8- } \\
\text { week-old infants with } \\
\text { jaundice }\end{array}$ & 110 & $\begin{array}{l}19(17,2 \%) \text { positif leukosituria } \\
13(68 \%) \text { positif leukosituria dan kultur urin } \\
16(14,5 \%) \text { positif leukosit esterase } \\
10(62,5 \%) \text { positif leukosit esterase dan kultur } \\
\text { urin } \\
3(2,7 \%) \text { positif nitrit } \\
3(100 \%) \text { positif nitrit dan kultur } \\
2(1,8 \%) \text { positif leukosituria, nitrit, dan leukosit } \\
\text { esterase } \\
2(100 \%) \text { positif leukosituria, nitrit, leukosit } \\
\text { esterase, dan kultur } \\
20(18 \%) \text { positif kultur urin }\end{array}$ \\
\hline 7. & $\begin{array}{l}\text { Ünsal H, } \\
\text { Kaman A, } \\
\text { Tanır G, } \\
2019 .{ }^{14}\end{array}$ & $\begin{array}{l}\text { Relationship between } \\
\text { urinalysis findings and } \\
\text { responsible pathogens } \\
\text { in children with } \\
\text { urinary tract infections }\end{array}$ & 705 & $\begin{array}{l}503(71,3 \%) \text { positif leukosit esterase } \\
202(28,6 \%) \text { negatif leukosit esterase, positif } \\
\text { kultur urin } \\
221(31,3 \%) \text { positif nitrit } \\
484(68,6 \%) \text { negatif nitrit, positif kultur urin } \\
705(100 \%) \text { positif kultur urin }\end{array}$ \\
\hline 8 & $\begin{array}{l}\text { Trihono PP, } \\
\text { Alkamdani R, } \\
\text { Hendarto A, } \\
\text { Astrawinata } \\
\text { DAW, 2019. }\end{array}$ & $\begin{array}{l}\text { Pewarnaan Gram urin } \\
\text { untuk diagnosis infeksi } \\
\text { saluran kemih pada } \\
\text { anak usia } 2 \text { bulan } \\
\text { hingga } 2 \text { tahun }\end{array}$ & 59 & $\begin{array}{l}15(25,4 \%) \text { positif leukosituria } \\
7 \text { anak positif leukosituria dan kulturu urin } \\
(46,6 \%) \\
5(0,08 \%) \text { positif nitrit } \\
3 \text { positif nitrit dan kultur urin }(60 \%) \\
8(13,5 \%) \text { positif leukosit esterase } \\
5 \text { positif leukosit esterase dan kultur urin } \\
(62,5 \%) \\
2(\%) \text { positif leukosituria, nitrit, dan leukosit }\end{array}$ \\
\hline
\end{tabular}




\begin{tabular}{|c|c|c|c|c|}
\hline 9 & $\begin{array}{l}\text { Shaikh N, } \\
\text { Shope MF, } \\
\text { Kurs-Lasky M, } \\
2019 .^{16}\end{array}$ & $\begin{array}{l}\text { Urine specific gravity } \\
\text { and the accuracy of } \\
\text { urinalysis }\end{array}$ & 10.258 & $\begin{array}{l}\text { esterase } \\
23(39 \%) \text { positif kultur urin } \\
10078(98,2 \%) \text { positif leukosit esterase } \\
1007(98,2 \%) \text { positif nitrit } \\
617(6,1 \%) \text { positif kultur urin }\end{array}$ \\
\hline 10 & $\begin{array}{l}\text { Khairina A, } \\
\text { Trihono PP, } \\
\text { Munazir Z, } \\
2014 .{ }^{17}\end{array}$ & $\begin{array}{l}\text { Urinalysis as a } \\
\text { diagnostic tool for } \\
\text { febrile urinary tract } \\
\text { infection in children } \\
\text { aged } 2 \text { months - } 2 \\
\text { years }\end{array}$ & 78 & $\begin{array}{l}\text { Sensitivitas dan spesifisitas leukosituria, nitrit, } \\
\text { leukosit esterase, pemeriksaan gabungan } \\
\text { leukosituri-nitrit, leukosituria-leukosit esterase } \\
\text { dan gabungan leukosituria, nitrit, dan leukosit } \\
\text { esterase berturut-turut yaitu } 56 \%, 86 \%, 24 \% \text {, } \\
94 \%, 68 \%, 80 \%, 33 \%, 94 \%, 70 \%, 90 \%, 46 \% \text {, } \\
95 \%\end{array}$ \\
\hline
\end{tabular}

Tabel 2. Hasil leukosituria positif

\begin{tabular}{ccccc}
\hline No & $\begin{array}{c}\text { Jumlah } \\
\text { sampel }\end{array}$ & $\begin{array}{c}\text { Sampel positif } \\
\text { leukosituria }\end{array}$ & $\begin{array}{c}\text { Sampel } \\
\text { positif ISK }\end{array}$ & $\begin{array}{c}\text { Positif leukosituria } \\
\text { dan kultur urin }\end{array}$ \\
\hline 1. & 34 & $3(9 \%)$ & $34(100 \%)$ & $3(9 \%)$ \\
2. & 120 & $5(4,2 \%)$ & - & - \\
3 & 110 & $19(17,2 \%)$ & $20(18 \%)$ & $13(68 \%)$ \\
Kisaran & & & $9-68 \%$ \\
\hline
\end{tabular}

Tabel 3. Hasil nitrit positif

\begin{tabular}{ccccc}
\hline No & $\begin{array}{c}\text { Jumlah } \\
\text { sampel }\end{array}$ & $\begin{array}{c}\text { Sampel } \\
\text { positif nitrit }\end{array}$ & $\begin{array}{c}\text { Sampel positif } \\
\text { ISK }\end{array}$ & $\begin{array}{c}\text { Sampel positif nitrit } \\
\text { dan kultur }\end{array}$ \\
\hline 1. & 1686 & $226(13,4 \%)$ & $542(32,1 \%)$ & $200(88 \%)$ \\
2. & 4147 & $1944(46,8 \%)$ & $289(7,0 \%)$ & $111(2,8 \%)$ \\
3. & 358 & $96(39,5 \%)$ & $243(68 \%)$ & $96(100 \%)$ \\
4. & 110 & $3(2,7 \%)$ & $20(18 \%)$ & $3(100 \%)$ \\
5. & 705 & $221(31,3 \%)$ & $705(100 \%)$ & $221(31,3 \%)$ \\
6. & 59 & $10(16,9 \%)$ & $23(39 \%)$ & $3(60 \%)$ \\
Kisaran & & & & $2,8-100 \%$ \\
\hline
\end{tabular}

Tabel 4. Hasil leukosit esterase positif

\begin{tabular}{ccccc}
\hline No & $\begin{array}{c}\text { Jumlah } \\
\text { Sampel }\end{array}$ & $\begin{array}{c}\text { Sampel Positif } \\
\text { Leukosit Esterase }\end{array}$ & $\begin{array}{c}\text { Sampel Positif } \\
\text { ISK }\end{array}$ & $\begin{array}{c}\text { Sampel Positif LE } \\
\text { dan kultur urin }\end{array}$ \\
\hline 1. & 1686 & $586(34,7 \%)$ & $542(32,1 \%)$ & $504(86 \%)$ \\
2. & 4147 & $3894(93,8 \%)$ & $289(7,0 \%)$ & $267(13,7 \%)$ \\
3. & 325 & $212(65,2 \%)$ & $210(65 \%)$ & $205(96,6 \%)$ \\
5. & 110 & $16(14,5 \%)$ & $20(18 \%)$ & $10(62,5 \%)$ \\
6. & 705 & $503(71,3 \%)$ & $705(100 \%)$ & $503(71,3 \%)$ \\
7. & 59 & $8(13,5 \%)$ & $23(39 \%)$ & $5(62,5 \%)$ \\
Kisaran & & & & $13,7-86 \%$ \\
\hline
\end{tabular}

Tabel 5. Hasil leukosituria positif dan nitrit positif

\begin{tabular}{c|cccc}
\hline No & Sampel & $\begin{array}{c}\text { Sampel positif } \\
\text { kultur urin }\end{array}$ & Sensitivitas & Spesifisitas \\
\hline 1. & 78 & $25(32 \%)$ & $33 \%$ & $94 \%$ \\
\hline
\end{tabular}


Tabel 6. Hasil leukosituria positif dan leukosit esterase positif

\begin{tabular}{c|cccc}
\hline No & Sampel & $\begin{array}{c}\text { Sampel positif } \\
\text { kultur urin }\end{array}$ & Sensitivitas & Spesifisitas \\
\hline 1. & 78 & $25(32 \%)$ & $70 \%$ & $90 \%$ \\
\hline
\end{tabular}

Tabel 7. Hasil leukosituria positif, nitrit positif, dan leukosit esterase positif

\begin{tabular}{ccccc}
\hline No & Sampel & $\begin{array}{c}\text { Sampel positif LU, } \\
\text { nitrit, dan LE }\end{array}$ & $\begin{array}{c}\text { Sampel } \\
\text { positif ISK }\end{array}$ & $\begin{array}{c}\text { Sampel positif LU, nitrit, } \\
\text { LE, dan ultur }\end{array}$ \\
\hline 1. & 110 & $2(1,8 \%)$ & $20(18 \%)$ & $2(100 \%)$ \\
2. & 59 & $4(6,7 \%)$ & $23(39 \%)$ & $4(100 \%)$ \\
Kisaran & & & $100 \%$ \\
\hline
\end{tabular}

Ket: LU, leukosituria; LE, leukosit esterase

\section{BAHASAN}

\section{Leukosituria positif}

Leukosit positif tidak dapat dijadikan patokan untuk mendiagnosis ISK, namun leukosituria negatif tidak dapat menyingkirkan adanya ISK. Penelitian oleh Pardede ${ }^{3}$ menyebutkan bahwa leukosituria pada ISK dapat dianggap bermakna, namun ISK juga dapat terjadi tanpa adanya leukosituria. Leukosituria juga dapat ditemukan pada keadaan kontaminasi vagina pada perempuan atau pada keadaan demam. Hal ini juga dibuktikan oleh Tusino dan Widyaningsih ${ }^{8}$ pada penelitiannya terhadap 34 pasien yang positif ISK dan $77 \%$ tidak terdeteksi adanya leukosit dalam urin. Pendapat ini juga semakin diperkuat oleh penelitian dari Tullus dan Shaikh $^{9}$ yang menyatakan meskipun leukosituria dijadikan sebagai salah satu persyaratan untuk mendiagnosis ISK namun telah dibuktikan bahwa pada $10 \%$ anak dengan ISK tidak ditemukan leukosituria; hal ini disebabkan karena leukosituria juga dapat ditemukan pada anak yang menderita demam atau penyakit infeksi selain ISK. Khairina et al ${ }^{17}$ menyatakan bahwa sensitivitas leukosituria sebesar $56 \%$, dan spesifisitas sebesar $86 \%$.

Sejalan dengan pernyataan yang telah dipaparkan, pada penelitian yang dilakukan oleh Tusino dan Widyaningsih ${ }^{8}$ dengan jumlah sampel sebanyak 34 orang, didapatkan hanya 3 anak (9\%) yang menderita ISK disertai dengan leukosituria positif dari 34 anak yang positif ISK. Triasta et $\mathrm{al}^{12}$ meneliti sebanyak 120 anak dan mendapatkan 5 anak (4,2\% yang positif leukosituria dari 120 anak yang dicurigai menderita ISK. Kelemahan penelitian ini ialah tidak dilakukan pemeriksaan kultur urin sebagai baku emas untuk mendiagnosis ISK. Penelitian oleh Trihono et $\mathrm{al}^{13}$ melaporkan bahwa dari 110 anak yang dijadikan sampel, 13 anak (68\%) mengalami leukosituria positif dari total anak yang positif ISK, dan sebanyak 20 anak $(18 \%)$ positif ISK.

Hasil kajian literatur mendapatkan kisaran ketepatan leukosituria positif yaitu sekitar 9-68\% (Tabel 1 dan 2).

\section{Nitrit positif}

Stein et $\mathrm{al}^{4}$ menyebutkan bahwa pemeriksaan nitrit positif sangat sensitif untuk mendiagnosis ISK, namun jika hasilnya negatif tidak dapat menyingkirkan adanya ISK. Demikian pula Alley ${ }^{18}$ mengemukakan pendapat yang sama, yakni jika hasil nitrit positif dapat dicurigai adanya ISK, namun jika hasilnya negatif tidak dapat menyingkirkan kemungkinan adanya ISK sebab terdapat keadaan tertentu yang dapat menyebabkan hasil nitrit negatif pada pasien dengan ISK, seperti terinfeksi oleh bakteri yang tidak dapat menghasilkan nitrit atau urin yang diperiksa merupakan urin yang belum lama tersimpan di kandung kemih. Prajapati ${ }^{19}$ pada penelitiannya menyatakan bahwa pemeriksaan nitrit urin tidak cocok pada bayi dan anak kecil untuk men- 
diagnosis ISK, sebab pada bayi dan anak kecil cenderung sering buang air kecil, dan bakteri dalam urin menghasilkan nitrit membutuhkan waktu sekitar 4 jam. Hal yang sama juga diungkapkan oleh Tullus dan Shaikh $^{9}$ yaitu spesifisitas pemeriksaan nitrit urin ini sangat tinggi untuk mendiagnosis ISK, namun sensitivitasnya hanya sekitar $50 \%$, dan pemeriksaan nitrit pada bayi dan anak-anak tidak cocok karena cenderung sering berkemih. Trinadi et $\mathrm{al}^{20}$ melaporkan bahwa nitrit memiliki spesifisitas sebesar $98 \%$ dan sensitivitasnya sebesar $53 \%$, dan nitrit dapat digunakan sebagai salah satu pemeriksaan untuk mendiagnosis ISK namun tidak dapat digunakan sebagai pemeriksaan yang menentukan diagnosis pasti, dan hanya untuk memrediksi kejadian ISK. Millner dan Becknell ${ }^{21}$ serta Roberts et $\mathrm{al}^{22}$ juga mengungkapkan hal yang serupa yaitu tes nitrit yang positif cukup spesifik untuk mendiagnosis ISK karena jarang terjadi hasil positif palsu, namun hasil yang negatif tidak dapat digunakan untuk menyingkirkan adanya ISK pada anak. Hal ini disebabkan pembentukan nitrit oleh bakteri membutuhkan waktu sekitar 4 jam sedangkan bayi dan anak-anak cenderung sering berkemih, serta tidak semua bakteri juga dapat menghasilkan nitrit, sehingga hasilnya bisa negatif palsu. Penelitian Phillipi dan Health $^{23}$ melaporkan sensitivitas pemeriksaan nitrit hanya sekitar $38 \%$, namun pemeriksaan ini jika digabungkan dengan pemeriksaan leukosit esterase, dan piuria dapat digunakan untuk mendiagnosis ISK pada anak. Hidayah et $\mathrm{al}^{24}$ menyatakan nilai sensitivitas dan spesifisitas dari nitrit sebesar $40 \%$, dan $81 \%$ sedangkan Julinawati et $\mathrm{al}^{25}$ menyatakan sensitivitas dan spesifisitas dari nitrit sebesar 73,8\%, dan 60,7\%. Menurut Khairina et al, ${ }^{17}$ nilai sensitivitas dan spesifisitas dari nitrit sebesar $24 \%$, dan $94 \%$. Selaras dengan hasil penelitian yang telah dipaparkan, Tullus dan Shaikh ${ }^{9}$ melaporkan bahwa dengan sampel sebanyak 1686 orang, 226 anak $(13,4 \%)$ mengalami nitrit positif, tetapi hanya terdapat 542 anak $(32,1 \%)$ yang terkonfirmasi ISK. Mahajan ${ }^{10}$ menggunakan sampel sebanyak 4147 anak dan mendapatkan 1944 anak (46,8\%) yang megalami nitrit positif, tapi hanya 289 anak $(7,0 \%)$ yang positif ISK.

Penelitian oleh Schroeder et $\mathrm{al}^{11}$ menggunakan tes nitrit terhadap sampel sebanyak 358 anak, dan mendapatkan 96 anak $(39,5 \%)$ dengan nitrit positif, tetapi anak yang positif ISK sebanyak 243 anak $(68 \%)$. Trihono et $\mathrm{al}^{13}$ menggunakan sampel sebanyak 110 anak, dengan hasil 3 anak $(2,7 \%)$ mengalami nitrit positif, tetapi terdapat 20 anak (18\%) yang positif kultur urin. Ünsal et $\mathrm{al}^{14}$ menggunakan jumlah sampel sebanyak 705 anak, dengan hasil 221 anak $(31,3 \%)$ positif nitrit urin, dari 705 anak $100 \%$ yang positif ISK. Pada penelitian yang berbeda dari Trihono et $\mathrm{al}^{15}$ dengan sampel sebanyak 59 anak didapatkan 10 anak $(16,9 \%)$ positif nitrit urin, dan terdapat 23 anak (39\%) yang positif kultur urin. Hasil penelitian oleh Shaikh et al ${ }^{16}$ dengan jumlah sampel sebanyak 10.258 anak, mendapatkan 1007 anak $(98,2 \%)$ positif nitrit, tetapi hanya 617 anak $(6,1 \%)$ yang positif kultur urin.

Hasil kajian literatur mendapatkan kisaran ketepatan nitrit positif yaitu sekitar 2,8-100\% (Tabel 1 dan 3).

\section{Leukosit esterase positif}

Tes leukosit esterase memiliki spesifisitas rendah namun memiliki sensitivitas yang baik untuk mendiagnosis ISK. Millner dan Becknell ${ }^{21}$ menyatakan bahwa leukosit esterase cukup sensitif untuk mendiagnosis ISK, namun leukosit esterase yang positif tidak selalu menunjukkan adanya ISK. Hal ini disebabkan karena tes ini memiliki spesifisitas rendah. Terdapat beberapa keadaan yang dapat menyebabkan leukosit esterase positif di antaranya ialah penyakit Kawasaki, glomerulonefritis, dan apendisitis. Hidayah et $\mathrm{al}^{24}$ melaporkan bahwa sensitivitas dan spesifisitas pemeriksaan leukosit esterase sebesar $88 \%$ dan $30 \%$. Penelitian oleh Julinawati et $\mathrm{al}^{25}$ menyatakan sensitivitas dan spesifisitas dari leukosit esterase sebesar $90,5 \%$ dan 39,3\% sedangkan Khairina et $\mathrm{al}^{17}$ mendapatkan nilai sensitivitas dan spesifisitas dari leukosit esterase sebesar $68 \%$ dan $80 \%$. Hasil penelitian tersebut sejalan dengan penelitian 
dari Tullus dan Shaikh ${ }^{9}$ yang menggunakan sampel sebanyak 1686 anak; 586 anak di antaranya $(34,7 \%)$ positif leukosit esterase dan 542 anak $(32,1 \%)$ positif kultur urin.

Penelitian oleh Mahajan ${ }^{10}$ dengan jumlah sampel sebanyak 4147 anak, melaporkan sebanyak 3894 anak $(93,8 \%)$ positif leukosit esterase, dan 289 anak $(7,0 \%)$ positif kultur urin. Schroeder et $\mathrm{al}^{11}$ menggunakan tes leukosit esterase pada 325 anak, dengan 212 anak $(65,2 \%)$ positif leukosit esterase dan 210 di antaranya (65\%) positif kultur urin. Triasta et $\mathrm{al}^{12}$ menggunakan sampel sebanyak 120 anak dengan hasil 2 anak $(1,7 \%)$ positif leukosit esterase. Namun, pada penelitian tersebut tidak dilakukan kultur urin sebagai pemeriksaan baku emas untuk mendiagnosis ISK, sehingga tidak ada pembanding.

Pada penelitian oleh Trihono et al $^{13}$ digunakan sampel sebanyak 110 anak, dengan 10 anak $(9,0 \%)$ positif leukosit esterase, tetapi terdapat 20 anak (18\%) yang positif kultur urin. Ünsal et al ${ }^{14}$ melaporkan bahwa dari 705 anak yang telah didiagnosis ISK, terdapat 503 anak di antaranya $(71,3 \%)$ positif leukosit esterase. Penelitian oleh Trihono et $\mathrm{al}^{15}$ dengan sampel sebanyak 59 anak mendapatkan hasil sebanyak 16 anak (27\%) positif leukosit esterase dan 23 anak $(39 \%)$ positif kultur urin. Shaikh et al ${ }^{16}$ menggunakan sampel sebanyak 10.258 anak mendapatkan 10078 anak $(98,2 \%)$ positif leukosit esterase, tetapi hanya 617 anak $(6,1 \%)$ yang positif kultur urin.

Hasil kajian literatur mendapatkan kisaran ketepatan leukosit esterase positif yaitu sekitar 13,7-86\% (Tabel 1 dan 4).

\section{Leukosituria positif, dan nitrit positif}

Pemeriksaan leukosituria memiliki nilai sensitivitas dan spesifisitas yang rendah, sedangkan pemeriksaan nitrit memiliki nilai sensitivitas yang rendah tapi memiliki nilai spesifisitas yang baik. Khairina et $\mathrm{al}^{17}$ melaporkan nilai sensitivitas dan spesifisitas gabungan pemeriksaan leukosituria dan nitrit sebesar 33\% dan 94\%.

Hasil kajian literatur mendapatkan kisaran ketepatan leukosituria positif dan nitrit positif berdasarkan sensitivitas dan spesifisitasnya yaitu 33\% dan 94\% (Tabel 1 dan 5).

\section{Leukosituria positif, dan leukosit esterase positif}

Pemeriksaan leukosituria memiliki nilai sensitivitas dan spesifisitas yang rendah, sedangkan pemeriksaan leukosit esterase meskipun memiliki nilai sensitivitas yang baik tetapi memiliki spesifisitas yang rendah. Khairina et $\mathrm{al}^{17}$ mengungkapkan nilai sensitivitas dan spesifisitas gabungan pemeriksaan leukosituria dan leukosit esterase sebesar $70 \%$, dan $90 \% .^{17}$

Hasil kajian literatur mendapatkan kisaran ketepatan leukosituria positif dan leukosit esterase positif berdasarkan sensitivitas dan spesifisitasnya yaitu $70 \%$, dan 90\% (Tabel 1 dan 6).

\section{Leukosituria positif, nitrit positif, dan leukosit esterase positif.}

Penelitian oleh Trihono et $\mathrm{al}^{13}$ menggunakan sampel sebanyak 110 anak, dan mendapatkan 2 anak $(1,8 \%)$ positif leukosituria, nitrit, dan leukosit esterase, namun yang positif ISK ialah 20 anak (18\%). Selain itu, penelitian yang berbeda oleh Trihono et $\mathrm{al}^{15}$ yang menggunakan sampel sebanyak 59 anak mendapatkan 4 anak $(6,7 \%)$ positif leukosituria, nitrit, dan leukosit esterase, tapi terdapat 23 anak (39\%) yang positif kultur urin. Khairina et $\mathrm{al}^{17}$ menggunakan sampel sebanyak 78 anak, dan mendapatkan 58 anak (75\%) yang positif leukosituria, nitrit dan leukosit esterase, namun hanya 25 anak (32\%) yang positif kultur urin.

Hasil kajian literatur mendapatkan kisaran ketepatan leukosituria positif, nitrit positif, dan leukosit esterase positif yaitu sekitar 100\% (Tabel 1 dan 7).

\section{SIMPULAN}

Leukosituria positif, nitrit positif, dan leukosit esterase positif dapat digunakan untuk mendiagnosis infeksi saluran kemih dengan sensitivitas dan spesifitas sebagai berikut: leukosituria positif memiliki sensitivitas dan spesifisitas rendah; nitrit positif memiliki spesifisitas baik tetapi 
sensitivitas rendah; dan leukosit esterase positif memiliki spesifisitas rendah dan sensitivitas baik.

Kombinasi leukosituria dan nitrit positif memiliki sensitivitas dan spesifisitas yang baik; leukosituria dan leukosit esterase positif memiliki sensitivitas dan spesifisitas yang baik; leukosituria, nitrit, dan leukosit esterase positif memiliki sensitivitas dan spesifisitas yang baik.

Diperlukan keterlibatan semua pihak, baik dari pihak pelayanan kesehatan maupun masyarakat, terutama orangtua agar lebih memperhatikan kebersihan organ genitalia eksterna anak, sehingga dapat menurunkan angka morbiditas dan mortalitas yang disebabkan oleh ISK. Perlu dilakukan penelitian lanjut mengenai pemeriksaan penunjang leukosituria, nitrit, dan leukosit esterase serta gabungannya dalam mendiagnosis ISK pada anak di Indonesia dengan jumah sampel besar untuk menentukan berapa besar ketepatan diagnosis dari pemeriksaan penunjang tersebut serta nilai sensitivitas dan spesifisitasnya.

\section{Konflik Kepentingan}

Penulis menyatakan tidak terdapat konflik kepentingan dalam studi ini.

\section{DAFTAR PUSTAKA}

1. Sherwood L, Alexander S. Introduction to Human Physiology Laurale Sherwood (8th International edition). Cossio Y, editor. Australia: Cengage Learning, 2013; p. 531-3.

2. Sekarwana N, Singadipoera SB, Bahrun D, Hilmanto D, Rachmadi D, Alatas H, et al. Buku Ajar Nefrologi Anak (2nd ed) Jakarta: Balai Penerbit FKUI, 2002.

3. Pardede SO. Infeksi saluran kemih pada anak manifestasi klinis dan tata laksana. Sari Pediatri. 2018;19(6):364-74.

4. Stein R, Dogan HS, Hoebeke P, Kocvara R, Nijman RJM, Radmayr C, et al. Urinary tract infections in children: EAU/ESPU guidelines. Eur Urol. 2015;67(3):54658. Doi: 10.1016/j.eururo.2014.11.007.

5. Malau UN, Adipireno P. Uji korelasi leukosit esterase dan nitrit dengan kultur urin pada infeksi saluran kemih. 2019;10(1): 184-7. Doi: 10.1556/ism.v10i1.343.
6. Muhajir A, Purwono PB, Handayani S. Gambaran terapi dan luaran infeksi saluran kemih oleh bakteri penghasil extended spectrum beta lactamase pada anak di RSUD Dr. Soetomo Surabaya. Sari Pediatri. 2016;18(2):111. Doi: 10.14238/sp18.2.2016.111-6.

7. Inayati I, Falah K. Uji diagnostik urinalisis lekosit esterase terhadap kultur urin pada pasien infeksi saluran kemih (ISK) dengan kateterisasi uretra, Syifa. Medika. 2014;4(2):100. Doi: 10.32502/sm.v4i2. 1406.

8. Tusino A, Widyaningsih N. Karakteristik infeksi saluran kemih pada anak usia 0- 12 tahun di RS X Kebumen Jawa Tengah. Biomedika. 2018;9(2):39-46. Doi: 10.23917/biomedika.v9i2.5842.

9. Tullus K, Shaikh N. Urinary tract infections in children. Lancet. 2020;395(10237): 1659-68. Doi: https://doi.org/10.1016/ S0140-6736(20)30676-0

10. Mahajan P, Tzimenatos L, Dayan PS, Vitale $\mathrm{M}$, Linakis JG, Blumberg $\mathrm{S}$, et al Accuracy of the urinalysis for urinary tract infections in febrile infants 60 days and younger. Pediatrics. 2020;141(2):27.

11. Schroeder AR, Chang PW, Shen MW, Biondi EA, Greenhow TL. Diagnostic accuracy of the urinalysis for urinary tract infection in infants <3 months of age. Pediatrics.2015;135(6):965-71. Doi: https://doi.org/10.1542/peds.2015-0012

12. Triasta T, Setiabudi D, Rachmadi D. Faktor risiko kecurigaan infeksi saluran kemih pada anak laki-laki usia sekolah dasar. Sari Pediatri. 2016;18(2):137. Doi: https://doi.org/10.14238/sp18.2.2016.1 37-41

13. Trihono P, Dewi AC, Gunardi H, Oswari H. Prevalence of urinary tract infection in 2-8-week-old infants with jaundice. Paediatrica Indonesiana. 2012;52(5): 304. Doi: https://doi.org/10.14238/ pi52.5.2012.304-8

14. Ünsal H, Kaman A, Tanır G. Relationship between urinalysis findings and responsible pathogens in children with urinary tract infections. Journal of Pediatric Urology. 2019;15(6):606.e1-606.e6. Doi: https://doi.org/10.1016/j.jpurol. 2019.09.017

15. Trihono, PP, Alkamdan, R, Hendarto A, Astrawinat, DAW. Pewarnaan Gram 
urin untuk diagnosis infeksi saluran kemih pada anak usia 2 bulan hingga 2 tahun. Sari Pediatri. 2019;20(4):230. Doi: $\quad$ https://doi.org/10.14238/sp20.4. 2018.230-6

16. Shaikh N, Shope MF, Kurs-Lasky M. Urine specific gravity and the accuracy of urinalysis. Pediatrics. 2019;144(5). Doi: https://doi.org/10.1542/peds.2019-0467

17. Khairina A, Trihono PP, Munazir Z. Urina-lysis as a diagnostic tool for febrile urinary tract infection in children aged 2 months2 years. Paediatrica Indonesiana. 2014;54(2):100. Doi: https://doi.org/ 10.14238/pi54.2.2014.100-8.

18. Alley ME. Urinary tract infections in the pediatric patient. Physician Assist Clin. 2020;1(4):639-60. Doi: 10.1016/j.cpha. 2016.06.002.

19. Prajapati H. Urinary tract infections in children. Paediatrics and Child Health (United Kingdom). 2018;28(7):318-23. Doi: 10.1016/j.paed.2018.04.009.

20. Trinadi I, Arguni E, Hermawan K. Validasi kriteria diagnosis infeksi saluran kemih berdasarkan American Academy of Pediatrics 2011 pada anak usia 2-24 bulan. Sari Pediatri. 2016;18(1):17-20.
21. Millner R, Becknell B. Urinary tract infections. Pediatr Clin North Am, 2019; 66(1):1-13. Doi: https://doi.org/10. 1016/j.pcl.2018.08.002

22. Roberts KB, Downs SM, Finnell SME, Hellerstein S, Shortliffe LD, Wald ER, et al. Urinary tract infection: clinical practice guideline for the diagnosis and management of the initial UTI in febrile infants and children 2 to 24 months. Pediatrics. 2011;128(3):595-610. Doi: https://doi.org/10.1542/peds.2011-1330.

23. Phillipi C, Health O. Diagnosing UTI in young febrile infants. AAP Grand Rounds. 2018;39(4):39. Doi: https://doi.org/ 10.1542/gr.39-4-39

24. Hidayah N, Kusuma A P, Noormanto (2011). Diagnostic tests of microscopic and urine dipstick examination in children with urinary tract infection. Paediatrica Indonesiana. 2011;51(5):252. Doi: https://doi.org/10.14238/pi51.5.2011.25 2-5

25. Julinawati S, Rina O, Rosmayanti, Ramayati R, Rusdidjas. Urine dipstick test for diagnosing urinary tract infection. Paediatrica Indonesiana. 2013;53(6):315. 